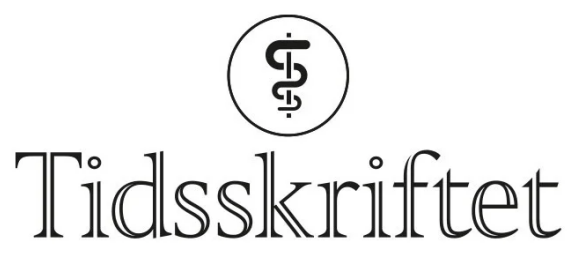

DEN NORSKE LEGEFORENING

\title{
Lokalanestetikum på norsk visitt
}

\author{
KOMMENTAR
}

\section{OLAV FLATEN}

olav.flaten@hunemo.no

Olav Flaten er dr.med. og tidligere medisinsk direktør.

Forfatter oppgir følgende interessekonflikter: Han var medisinsk ansvarlig i Apothekernes Laboratorium AS i tiden denne historien refererer til.

Reigstad og Reigstad hadde en interessant artikkel om lokalbedøvelsens historie og den rolle den har hatt for medisinsk praksis (1). En kuriøs historie fra Norge kan knyttes til denne historien.

Den kreative Bo af Ekenstam var kjemiker på AB Bofors Nobelkrut der han utviklet sine amid-substanser som viste seg som gode lokalanestetika (2). Butyl-formen bupivakaine og metyl-formen mepivakaine ble overtatt og videreutviklet av Astra. Men suksessen til disse overskred aldri lidokain, og Astra var ikke interessert i den tredje substansen, propylformen, som Bo fikk beholde rettighetene til selv.

Norske Apothekernes Laboratorium AS (AL) fikk disse rettighetene mens jeg var medisinsk ansvarlig der i første del av 1980-årene. Det ble min oppgave å være med på utviklingen av denne substansen. Vi gjorde studier blant annet ved Universitetet i Linkøping, vi søkte og fikk innvilget USA-patent (3), og vi søkte WHO om et generisk navn (INN). Vi søkte om navnet propivakaine, men WHO satte ropivakaine som generisk navn. AL hadde ikke noen erfaring eller tradisjon på dette området. Men resultatene var gode, og da vi kontaktet Astra, ble de interessert, og overtok patentet og produktet som ble videreutviklet og markedsført.

Bo af Ekenstam fortalte også om utviklingen av bupivakaine. Han testet det på seg selv, satte «kvadler» subkutant og målte effekt av nummenhet i tid og utstrekning. Han var også selv første pasient: Han skulle rotfylle en tann, og tok med substansen til sin tannlege og ba om at den ble benyttet som bedøvelse. Bo var fortsatt nummen i leppen dagen etter. Litt annen type klinisk utprøvning i de dager!

\section{LITTERATUR}

1. Reigstad A, Reigstad O. Lokalbedøvelsens historie - fra kokablader til effektiv analgesi. Tidsskr Nor Legeforen 2021; 141. doi:10.4045/tidsskr.21.0381. [PubMed][CrossRef]

2. Ekenstam BA, Egner B, Pettersson G. Local Anaesthetics I. N-Alkyl Pyrrolidine and N-Alkyl

Piperidine Carboxyloxic Acid Amides. Acta Chem Scand 1957;

http://actachemscand.org/pdf/acta_vol_11_p1183-119o.pdf 
Publisert: 31. januar 2022. Tidsskr Nor Legeforen. DOI:10.4045/tidsskr.22.0021

(C) Tidsskrift for Den norske legeforening 2023. Lastet ned fra tidsskriftet.no 26. april 2023. 